\title{
Transformation Fava Beans by Agrobacterium using Chitinase, Glucanase and CryIA (b) genes
}

\author{
A.H.Gorji ${ }^{\#}$ Zahra Zolnori,A.Jamasbi and Y.Khodadadzadeh \\ \# Department of Plant Breeding,Faculty of Agriculture,Broujerd Branch,Islamic Azad University, Broujerd, Iran \\ E-mail: Amirhgorji@yahoo.com
}

\begin{abstract}
In this study two plasmid vectors that are appropriate for plant transformation were made by preparation of gene cassettes for $\beta$-1, 3glucanase from barley, chitinase from bean and cryIA (b) from Bacillus thuringiensis (BT). Each of these genes were cloned under the control of the CaMV35S promoter and the Nos terminator in pBI121 binary vector. pBI-Chi and pBI-Glu and recombinant plasmid vectors were constructed via cloning of chitinase , $\beta$-1,3- glucanase and cryIA (b) genes, respectively, instead of the gus gene in T-DNA region of pBI121 vector. Construction of pBI-ChiGlu recombinant plasmid vector was performed by means of cloning both of the complete chitinase and glucanase gene cassettes in pBI121 vector, with the intention of production synergistic effects against fungal infection.pBI-ChiBt recombinant plasmid vector containing both of the complete chitinase and Bt gene cassettes was also constructed in order to contemporaneous plants resistance to pest pathogens and fungal in a single transformation event. pBI-ChiGlu and pBI-ChiBt that have been introduced into the A. tumefaciens strain LBA4404 that was subsequently used for transformation. Results indicate that embryogenic calli are well appropriate as objective material for Agrobacterium tumefaciens-mediated transformation in Faba bean.Seventeen well established shoots were transferred to new MLS medium including suitable antibiotics.Finally six independent transgenic plants were successfully rooted on kanamycin-containing selection media and then transferred to soil after 20 days .Four plants out of six putative transgenic plants displaied to contain the end part of the chit transgene and nos terminator.The corresponding piece, $700 \mathrm{bp}$ of the chit gene, was amplified using specific primer.These putative transgenic plants were also be measured for the presence of the bgn13.1 and cryIA (b) genes by PCR using specific primers.Two pieces with expected sizes (1221 bp and 640 bp) for bgn13.1 and cryIA (b) genes subsequently was amplified from three the transgenic plants and other three plants had not these fragments.A group of virG primers was used to discover Agrobacterium pollution that might have threw off the selection. Expression of chit, and $\beta$-1,3-glucanase genes at the transcriptional level in the transformed plants were proven by means of RT-PCR but expression of $\operatorname{cryI} A(b)$ was not proven. The expected dimension of the amplified cDNA pieces were identificated in the transformed plants, that confirming the permanent annexation and expression of T-DNA in the genome of kanamycinscreened plants.
\end{abstract}

Keywords - Agrobacterium ,ß-1,3-glucanase; BT; Chitinase; Cloning; Recombinant Plasmid

\section{INTRODUCTION}

Faba bean ( Vicia faba L. ) is one of the most important food legumes in some countries such as Iran,Egypt,Greece,Ethiopia and Nepal.Like many other crops, the production of this crop is challenged by a number of plant pathogens and parasites. One of the most important fungal disease for this crop is Faba bean Root Rot, and causes considerable losses in the yield of faba bean in Iran(fig 1).The mycoparasitic process involves varied fungal cell wall degrading enzymes, including hydrolytic enzymes (Chet et al., 1998).Among these enzymes, $\beta$-1,3-glucanases and chitinases are appealing molecules because they have activity against a vasty range of fungi (Walsh et al., 2000). $\beta$ 1,3-glucanases and Chitinases have been shown to have strong antifungal activities when used in combination (Lorito et al., 1998). Chitinases also confer broad resistance to other biotic and abiotic stresses, such as salinity, heavy metals and bacterial pathogens (Dana et al., 2006).
In this study the chitinase gene from bean, the $\beta-1,3-$ glucanase gene from barley and cryIA (b) from Bacillus thuringiensis (BT) are used and have been replaced instead T-DNA of pBI121 plasmid(Fig 2). Faba bean cultivar is transformed by Agrobacterium-mediated transformation method.The plants that is being transgenic are analyzed by PCR and RT-PCR, and tested for their antifungal activity.

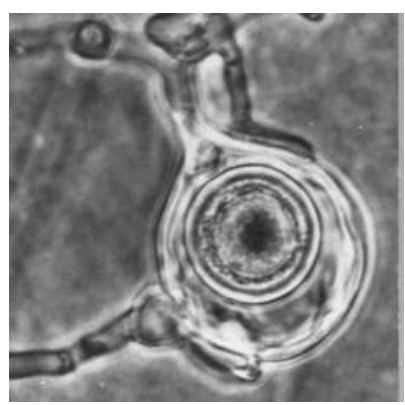

Fig 1. Aphanomyces root rot or common root rot of legumes 


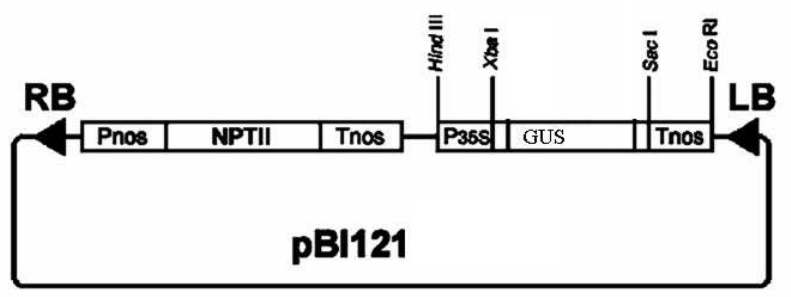

Fig 2. The physical map plasmid T-DNA of pBI121

\section{MATERIALS AND METHODS}

An economically important faba bean of the Dehano cultivar, was used as the receptor. Fusarium. solan, the causal important agent of Faba bean root rot was propagated and subcultured as needed.Bacteria were grown in EMB medium at appropriate temperatures $\left(30^{\circ} \mathrm{C}\right.$ for $\mathrm{A}$. tumefaciens and $37^{\circ} \mathrm{C}$ for E. coli) with shaking (160 rpm). Agrobacterium tumefaciens LBA4404 was used for the plant transformation method and Escherichia coli $\mathrm{O} 157 \mathrm{H} 7$ was used in whole molecular experiments.E. coli $\mathrm{O} 157 \mathrm{H} 7$ was transformed using the $\mathrm{CaCl} 2$ method. Cloneis of the A.tumefaciens LBA4404,placing recombinant plasmids (pBI-ChiGlu and pBI-ChiBt that have been made by method of Mohsenpour et al,2008) containing $\beta$-1,3-glucanase , cryIA (b) and chitinase genes, were grown in EMB medium supplemented whit $50 \mathrm{mg} / \mathrm{l}$ of kanamycin and allowed to grow overnight at $27^{\circ} \mathrm{C}$ with constant shaking (200 rpm) to mid-log phase(Fig 3 and Fig 4).

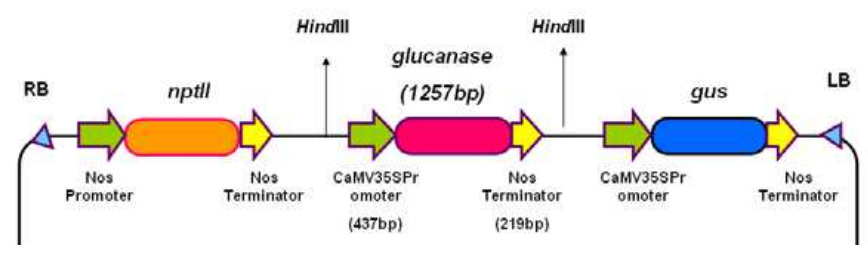

Fig 3. The physical map recombinant plasmid of pBI121-Glu

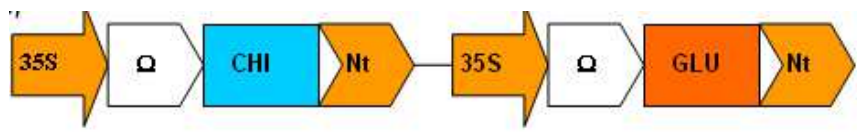

Fig 4. One sample of construction used for the transformation with antifungal genes

The bacterial cells were provided by centrifugation and resuspended in infection medium Murashige and Skoog (MS) medium, $70 \mathrm{mg} / \mathrm{l}$ of sucrose, $(\mathrm{pH}$ 5.7) and were then shaken for $2.5 \mathrm{~h}$ at $27^{\circ} \mathrm{c}$.Explants of axis below the cotyledons were infected with A. tumefaciens LBA4404. Infected explants were co-cultivated for 4 days on MLS medium (Linsmaier and Skoog, 1965) containing MS macro salts, LS micro salts, $8 \mathrm{mg} / \mathrm{l}$ of thiamine- $\mathrm{HCl}, 100 \mathrm{mg} / \mathrm{l}$ of inositol, $2 \mathrm{mg} / \mathrm{l}$ of $6-$ benzylaminopurine(BAP), $8 \mathrm{mg} / \mathrm{l}$ of adenine sulfate, $1 \mathrm{mg} / \mathrm{l}$ of zeatin, $7.5 \mathrm{~g} / \mathrm{l}$ of agar (Sigma)and $20 \mathrm{~g} / \mathrm{l}$ of sucrose without any antibiotics in dim light(white fluorescent light; $15 \mathrm{mE} / \mathrm{m} / \mathrm{s})$ at $22^{\circ} \mathrm{C}\left( \pm 2^{\circ} \mathrm{C}\right)$. The MLS medium was regulated to $\mathrm{pH} 5.7$ with $1 \mathrm{~N} \mathrm{HCl}$ before adding agar. The growth regulator BAP was surcharged to the medium before autoclaving,but zeatin was filter sterilized and then added to the autoclaved medium.After co-cultivation, putrefied slices were washed by MS medium and distilled water, which had an proportionate concentration of cefotaxime $(500 \mathrm{mg} / \mathrm{l})$ for Agrobacterium removal.Then, they were transferred to MLS medium including cefotaxime $(500 \mathrm{mg} / \mathrm{l})$ and kanamycin $(100 \mathrm{mg} / \mathrm{l})$.Major of the primary shoots were not transgenic and incapable to grow on selective media.Subsequent emerging shoots on antibiotic including media were transferred to MS medium containing cefotaxime (500 $\mathrm{mg} / \mathrm{l})$ and kanamycin $(100 \mathrm{mg} / \mathrm{l})$.After 17 days, the rooted plantlets were moved to soil. Leaf material from transgenic and non-transgenic plants was harvested, dried by freezing hard and squelched into powder for extraction of genomic DNA (modified CTAB procedure).PCR amplification was used for inception molecular affirmation of the presence of transgenes.DNA fragment including the $\beta$-1,3-glucanase , cryIA (b) and chitinase genes was amplified by PCR using specific primers (Table 1).PCR was carried out as follows: an initial denaturation at $93^{\circ} \mathrm{C}$ for $4 \mathrm{~min}$ followed by 40 cycles of denaturation at $94^{\circ} \mathrm{C}$ for $1 \mathrm{~min}$, annealing at $62^{\circ} \mathrm{C}$ for chitinase gene in $1 \mathrm{~min}, 55^{\circ} \mathrm{C}$ for $\beta$-1,3-glucanase gene in 3 min and $60{ }^{\circ} \mathrm{C}$ for crylA (b) gene in 2 min,extention at $72^{\circ} \mathrm{C}$ for $2 \mathrm{~min}$ and a final extension at $72^{\circ} \mathrm{C}$ for $8 \mathrm{~min}$. The resulting PCR products were detached by electrophoresis on $1 \%(\mathrm{w} / \mathrm{v})$ agarose gel.Specific mRNAs of the transgene were checked using reverse transcriptase RT-PCR.All RNA was isolated from leaves of transgenic and control plants.PCR amplification was achieved using the first strand cDNA as template with chitinase, cryIA (b) and glucanase gene specific primers .The antifungal activity of half-baked juice from the transgenic plants was tested using a modification of the radial distribution method (Broglie et al., 1991).The leaf material $(5 \mathrm{~g})$ was stand to a fine powder in liquid nitrogen using a pounder and pestle. Two volumes of $1 \mathrm{M} \mathrm{NaCl}$ in 20 $\mathrm{mM} \mathrm{NaOAc}(\mathrm{pH} 4.7)$ were excessed to the leaf material.The juices were then shaken for $2 \mathrm{~h}$ at $45^{\circ} \mathrm{C}$ and subsequently centrifuged at $13000 \mathrm{~g}$ for $30 \mathrm{~min}$ at $45^{\circ} \mathrm{C}$.Protein content of juices was distinguished.

An agar disc (5 $\mathrm{mm}$ in diameter)containing Fusarium. solani, which was taken from the fungus in an actively growing state, was placed at the center of a Petri dish .In continuance the plates were incubated at $30^{\circ} \mathrm{C}$ for 3 days.Wells were subsequently pierced into the agar at a interval of $25 \mathrm{~mm}$ from the center of the plates. Then for the samples to be examined those were mixed with $10 \mu \mathrm{l}$ of 15 $\mathrm{mM}$ acetate sodium buffer, $\mathrm{pH} 4$ and placed in the wells.

TABLE I

THE SEQUENCE OF PRIMERS USED IN PCR AND RT-PCR ANALYSIS.

\begin{tabular}{|l|l|}
\hline $\begin{array}{l}\text { Primer number and } \\
\text { application }\end{array}$ & Sequence \\
\hline 1-for Chit forward & 5-GAGTGGTGTGGATGCTGTTG-3 \\
\hline 2-for chit reverse & 5-GCCATAACCGACTCCAAGCA-3 \\
\hline $\begin{array}{l}\text { 3-for } \beta \text {-1,3-glucanase } \\
\text { forward }\end{array}$ & 5-GAACATCAAGTACATCGCCG-3 \\
\hline $\begin{array}{l}\text { 4-for } \beta \text {-1,3-glucanase } \\
\text { reverse }\end{array}$ & 5-GCTACACGTACTAGAACTGG-3 \\
\hline 5-for cryIA $(b)$ forward & 5-CTCTAGGTTGGAAGGATTGAG-3 \\
\hline 6- for cryIA $(b)$ reverse & 5-GTGAGCATCGGTGTAGATAG-3 \\
\hline
\end{tabular}




\section{RESULTS}

pBI-ChiGlu and pBI-ChiBt that have been introduced into the A. tumefaciens strain LBA4404 was subsequently used for transformation. Shoots were cocultivated and after 4 days, the slices were rinsed and transferred to selection medium containing cefotaxime and kanamycin. These results indicate that embryogenic calli are well appropriate as objective material for Agrobacterium tumefaciensmediated transformation in Faba bean.Most shoots that was growing on selective media were shown to be nontransgenic.Seventeen well established shoots (3-4.5 cm long) were transferred to new MLS medium including suitable antibiotics.Finally six independent transgenic plants were successfully rooted on kanamycin-containing selection media and then transferred to soil after 20 days .Only one well-grown shoot from each infected explant was transferred to rooting medium.

Four plants out of six putative transgenic plants displaied to contain the end part of the chit transgene and nos terminator.The corresponding piece, $700 \mathrm{bp}$ of the chit gene, was amplified using specific primer.

These putative transgenic plants were also be measured for the presence of the bgn13.1 and cryIA (b) genes by PCR using specific primers.Two pieces with expected sizes (1221 bp and $640 \mathrm{bp}$ ) for bgn13.1 and cryIA (b) genes subsequently was amplified from three the transgenic plants and other three plants had not these fragments. The results this study indicated that the transgenic plants were transformed by these three genes.The chit42, bgn13.1 and cryIA (b) specific primers did not amplify the corresponding pieces in the untransformed samples.A group of virG primers was used to discover Agrobacterium pollution that might have threw off the selection. PCR under various qualifications showed no scrutable bands using transgenic plant DNA as template. A 738 bp band was identification using Agrobacterium DNA as control.Expression of chit , and $\beta-1,3$-glucanase genes at the transcriptional level in the transformed plants were proven by means of RT-PCR and expression of cryIA(b)was not proven.

RNA was isolated from leaf tissues for production of cDNA.The expected dimension of the amplified cDNA pieces were identificated in the transformed plants, that confirming the permanent annexation and expression of $\mathrm{T}$ DNA in the genome of kanamycin-screened plants.Nontransformed plants were applied as negative controls and no PCR products were recognited.For test the antifungal activity of expressed Chit42 and Bgn13.1 from transgenic plants on the actively growing phytopathogenic fungus fusarium. solani, total protein extracts from leaves of transgenic and non-transgenic plants were examined with using the radial diffusion assay. Antifungal activity was detected in extracts from two RT-PCR positive plants. Antifungal activity was not looked in other leaf juices .

\section{IV.DISCUSSION AND CONCLUSIONS}

Crops often suffer from diverse diseases caused by microbes covering phytopathogenic fungi,resulting in reduced yield and quality of products.Faba bean can be attacked by fungal diseases, such as rust (Uromyces viciaefabae) and chocolate spot (Botrytis fabae). It is also attacked by the black bean aphid (Aphis fabae) and Faba bean Root Rot. This fungus causes serious losses in yield. Cell wall degrading enzymes such as glucanases and chitinases from mycoparasitic fungi have shown high antifungal activity versus a wide range of economically important fungi (Harighi et al., 2006). The last two decades attempts have been made on the transgenic expression of plant fungal chitinases in crops, and significant developments in the resistance to fungal diseases have been registered (Nandakumar et al., 2005; Rajasekaran et al., 2005; Pappinen et al.,2002).Plant chitinases have been indicated that injunct fungal growth in vitro by degrading chitin polymers in fungal cell walls (Noel et al., 2005). Copy number of the transgene is one of the most important agents implied in the durability of gene expression in transgenic plants (Katleen et al, 2005). Meaningful differences in the level of expression of the chitinase gene among the transgenic for cotton have been reported (Tohidfar et al.,2005). A positive relation was appointed between the level of chitinase expression and prevention of fungal growth and damage.Many reports have demonstrated that $\beta$ 1,3-glucanases are distinct in their gene regulation (Romero et al., 1998) .Before, activity of $\beta$-1,3-glucanases in pea seedlings has been proved.All $\beta$-1,3-glucanases are expressed in leaves in response to pathogens. The function of $\beta$-1,3-glucanases in floral tissues is well understood in anthers.Some researches have been performanced to expand transgenic crop plants that have raised expression levels of the cell wall degrading enzymes in hopes of producing fungal disease-resistant varieties (Datta et al., 2001). Prior studys have also shown that elevated chitinase activity in transgenic strawberry (ASAO et al. 1997), rice (NISHIZAWA et al. 1999), tobacco (EMANI et al. 2003).There are many reports about the benefits of using chitinases for plant preservation (Jayaraj and Punja, 2007; Xiao et al., 2007).However, there are almost no reports demonstrating that chitinase genes derived from plants or bacteria allow resistance to several fungi in transgenic plants, showing that these enzymes have a slender range of antifungal activity (Dana et al., 2006). The failed use of plant chitinases for plant protection maybe comes from the fact that the gene codes for enzymes that usually affect only the hyphal tip and lack the capability to efficiently degrade spores or hard chitin constructions (Joosten et al., 1995).

Whereas fungal chitinases are able to lyse not only the hyphal tip, but also the strict chitin wall of the complete hyphae and other fungal maintenance structures (Lorito et al.,1998).Also, there are some researches on the expansion of transgenic plants with glucanase genes for producing fungal disease resistant varieties (Datta et al., 2001).Multiple reports explain the synergic interplay effects of $\beta-1,3-$ glucanase and chitinase in antifungal protection and these enzymes are non-toxic (Moravcikova et al., 2007;Dana et al.,2006).Usage of multifold resistant transgenes with distinct mechanisms to crop genetic manipulations could widen the range and increase the level of resistance in transgenic plants(Zhu et al., 2007). Some PCR-positive plants failed to express the corresponding mRNA when further analyzed by the RT-PCR method, thus demonstrateing the silencing of these genes. Silencing of transgenes, have also been reported in some other transgenic 
plants (Khan et al., 2008; Chang et al., 2002). Crude protein juices from the transgenic plants were able to prolong the hyphal growth of the fungal pathogen F. solani in the in vitro experiment.

\section{REFERENCES}

[1] Asao, H.; Nishizawa, Y.; Arai, S.; Sato, T.; Hirai, M.; Yoshida, K.; Shinmyo, A.; Hibi, T.; 1997: Enhanced resistance against a fungal pathogen Sphaerotheca humuli in transgenic strawberry expressing a rice chitinase gene. Plant Biotechnol. 14, 145-149.

[2] Attia,M.F.; Abou-Zeid, N.M.;Abada, K.A.; Soliman, M.H. and Noha. F. El-Badawy(2007). Isolation of chitinase gene induced during infection of Vicia faba by Botrytis fabae. Arab J. Biotech., Vol. 10, No. (2) July (2007):289-300.

[3] Broglie K, Chet I, Holliday M, Cressman R, Biddle P, Knowlton S,Mauvais CJ, Broglie R (1991). Transgenic plants with enhanced resistance to the fungal pathogen Rhizoctonia solani. Science 254: 1194-1197.

[4] Chang MM, Culley D, Choi JJ, Hadwiger LA (2002).Agrobacteriummediated cotransformation of a pea $\beta$-1,3-glucanase and chitinase genes in potato (Solanum tuberosum L. cv. Russet Burbank) using a single selectable marker. Plant Sci. 163: 83-89.

[5] Chet I, Benhamou N, Haran S (1998). Mycoparasitism and lytic enzymes. In: Harman G.E. and Kubicek C.P. (Eds.),Trichoderma and Gliocladium. Vol 2. Taylor and Francis,London. PP. 153-172.

[6] Dana MdIM, Pintor-Toro JA, Cubero B (2006). Transgenic tobacco plants overexpressing chitinases of fungal origin show enhanced resistance to biotic and abiotic stress agents. Plant Physiol. 142: 722730 .

[7] Datta K, Tu J, Oliva N, Ona I, Velazhahan R, Wew TW,Muthukrishnan S, Datta, SK (2001). Enhanced resistance to sheath blight by constitutive expression of infection-related rice chitinase in transgenic elite indica rice cultivars. Plant Sci. 160: 405414.

[8] Emani, C.; Garcia, J. M.; Lopata-Finch, E.; Pozo, M. J.; Uribe, P.; Kim, D.J.; Sunilkumar, G.; Cook, D. R.; Kenerley, C. M.; Rathore, K. S.;2003: Enhanced fungal resistance in transgenic cotton expressing an endochitinase gene from Trichoderma virens. Plant Biotech. J. 1,321-326.

[9] Harighi MJ, Motallebi M, Zamani MR (2006). Purification of chitinase 42 from Trichoderma atroviride PTCC5220. Iran J Biol. 19: 203-214.

[10] Jayaraj J, Punja ZK (2007). Combined expression of chitinase and lipid transfer protein genes in transgenic carrot plants enhances resistance to foliar fungal pathogens. Plant Cell Rep. 26: 1539-1546.

[11] Joosten MHAJ, Verbakel HM, Nettekoven ME, van Leeuwen J,van der Vossen RTM, de Wit PJG M (1995). The phytopathogenic fungus Cladosporium fulvum is not sensitive to the chitinase and $\beta$ 1,3-glucanase defence proteins of its host,tomato. Physiol Mol Plant Pathol. 46: 45-49.

[12] Katleen MJ, Butaye PA Cammue SL, Delaure M FC (2005).Approaches to minimize variation of transgene expression in plants. Mol Breed. 16: 79-91.
[13] Khan RS, Sjahril R, Nakamura I, Mii M (2008). Production of transgenic potato exhibiting enhanced resistance to fungal infections and herbicide applications. Plant Biotechnol Rep.2: 13-20.

[14] Lorito M, Woo SL, Fernandez IG, Colucci G, Harman GE, PintorToro JA, Filippone E, Muccifora S, Lawrence CB, Zoina A,Tuzun S, Scala F (1998). Genes from mycoparasitic fungi as a source for improving plant resistance to fungal pathogens.Proc Natl Acad Sci USA. 95: 7860-7865.

[15] Mohsenpour, M., Babaeian, N.A. , Tohidfar,M.and Habashi3, A.A(2008). Design and construction of four recombinant plasmid vectors containing chitinase, glucanase and BT genes, suitable for plant transformation. J. Agric. Sci. Natur. Resour., Vol. 15(4)

[16] Moraveikova J, Libantova J, Heldak J, Salaj J, Bauer M,Matušikova I, Galova Z, Mlynarova L'(2007). Stress-induced expression of cucumber chitinase and Nicotiana plumbaginifolia $\beta$-1,3-glucanase genes in transgenic potato plants. Acta Physiol Plant. 29: 133-141.

[17] Nandakumar R, Babu S, Radjacommare R, Raguchander T,Samiyappan R (2005). Pseudomonas fluorescens mediated antifungal activity against $R$. solani, sheath blight pathogen.Phytopathol Mediterr. 41: 109-119.

[18] Nishizawa, Y.; Nishio, Z.; Nakazono, K.; Soma, M.; Nakajima, E.; Ugaki,M.; Hibi, T.; 1999: Enhanced resistance to blast (Magnaporthe grisea) in transgenic japonica rice by constitutive expression of rice chitinase. Theor. Appl. Genet. 99, 383-390.

[19] Noel A, Levasseur C, Le VQ, Seguin A (2005). Enhanced resistance to fungal pathogens in forest trees by genetic transformation of black spruce and hybrid poplar with a Trichoderma harzianum endochitinase gene. Physiol Mol Plant Pathol. 67:92-99.

[20] Rajasekaran K, Cary JW, Jaynes JM, Cleveland TE (2005).Disease resistance conferred by the expression of a gene encoding a synthetic peptide in transgenic cotton (Gossypium hirsutum L.) plants. Plant Biotechnol J. 3: 545-554.

[21] Romero, G.O., Simmons, C., Yaneshita, M., Doan, M., Thomas,B.R. and Rodriguez, R.L. 1998. Characterization of rice endo- $\beta$-glucanase genes (Gns2-Gns14) defines a new subgroup within the gene family. Gene 223: 311-320.

[22] Rajasekaran K, Cary JW, Jaynes JM, Cleveland TE (2005).Disease resistance conferred by the expression of a geneencoding a synthetic peptide in transgenic cotton (Gossypium hirsutum L.) plants. Plant Biotechnol J. 3: 545-554.

[23] Tohidfar M, Mohammadi M, Ghareyazie B (2005). Agrobactrium mediated transformation of cotton (Gossypium hirstum) using a hetrologous bean chitinase gene. Plant Cell Tissue Organ Cult. 83: 83-96.

[24] Walsh TJ, Viviani MA, Arathoon E, Chiou C, Ghannoum M, Groll AH, Odds FC (2000). New targets and delivery systems for antifungal therapy. Med Mycol. 38: 335-347.

[25] Xiao YH, Li XB, Yang XY, Luo M, Hou L, Guo SH, Luo XY, Pei Y (2007). Cloning and characterization of a balsam pear class I chitinase gene (Mcchit1) and its ectopic expression enhances fungal resistance in transgenic plants. Biosci Biotechnol Biochem. 71: 12111219.

[26] Zhu H, Xu X, Xiao G, Yuan L, Li B (2007). Enhancing disease resistances of Super Hybrid Rice with four antifungal genes.Sci China C Life Sci. 50: 31-39. 